medRxiv preprint doi: https://doi.org/10.1101/2021.12.28.21268496; this version posted December 31, 2021. The copyright holder for this preprint (which was not certified by peer review) is the author/funder, who has granted medRxiv a license to display the preprint in perpetuity.

It is made available under a CC-BY-NC-ND 4.0 International license .

\title{
The Effect of Weather Pattern on the Second Wave of Coronavirus: A cross study between cold and tropical climates of France, Italy, Colombia, and Brazil
}

\author{
Ahmed Islam ${ }^{\dagger}$ \\ $\dagger$ Department of Mechanical Engineering, University of Louisville \\ For correspondence: ahmed.islam@louisville.edu
}

\begin{abstract}
This study aims to explore and understand the common belief that COVID infection rate is highly dependent on either the outside temperature and/or the humidity. Thirty-six regions/states from two humid-tropical countries, namely Brazil and Colombia and two countries with temperate climate, France and Italy, are studied over the period of October to December. Daily outside temperature, relative humidity and hospitalization/cases are analyzed using Spearman's correlation. The eighteen cold regions of France and Italy has seen an average drop in temperature from $10^{\circ} \mathrm{C}$ to $6^{\circ} \mathrm{C}$ and $17^{\circ} \mathrm{C}$ to $7^{\circ} \mathrm{C}$, respectively, and France recorded an addition of 2.3 million cases, while Italy recorded an addition of 1.8 million cases. Outside temperature did not fluctuate much in tropical countries, but Brazil and Colombia added 4.17 million and 1.1 million cases, respectively. Köppen-Geiger classification showed the differences in weather pattern between the four countries, and the analysis showed that there is very weak correlation between either outside weather and/or relative humidity alone to the COVID-19 pandemic.
\end{abstract}

\section{Introduction}

Recent studies by different researchers show that weather temperature, humidity and precipitation may have largely contributed to the spread of influenzas and airborne viruses that are mediated through the means of aerosol droplets of different sizes. Human to human transmission of acute 
medRxiv preprint doi: https://doi.org/10.1101/2021.12.28.21268496; this version posted December 31, 2021. The copyright holder for this preprint (which was not certified by peer review) is the author/funder, who has granted medRxiv a license to display the preprint in perpetuity.

It is made available under a CC-BY-NC-ND 4.0 International license .

24 respiratory viruses, such like SARS-CoV-2, has turned into a widespread pandemic, with large

25 fractions of infected patients suffering from acute respiratory distress syndrome (ARDS) and

26 needing non-invasive and invasive mechanically ventilated interventions[1]. While the virus

27 persisted throughout the year of 2020, hospitalizing thousands of patients all across the United

28 States, many researchers claimed that the pattern of rise-fall-rise (winter-summer-winter) of the

29 rate of daily infections indicates that the respiratory virus has a strong correlation with the

30 seasonality, particularly with the changes in temperature, relative humidity (RH), absolute

31 humidity (AH) and host behavior[2]-[4].

32 Because of the potential resemblance of typing of SARS-CoV-2, researchers have studied

33 surrogate models to find out the survivability under different environmental settings. Typical

34 healthcare environments with varying relative humidity $(\mathrm{RH})$ but an ambient temperature $(\mathrm{AT})$ at

35 around 20C showed that potential surrogate virus types like transmissible gastroenteritis virus

36 (TGEV) and mouse hepatitis virus (MHV) loose very small infectivity within a period of two days.

37 Studies also indicated that TGEV and human coronavirus 229E survivability at low temperature

38 and medium and low RH is rather enhanced.

39

40

41

42

43

44

45

46

A recent COVID-19 study [5] on droplet dynamics showed that the spreading and concentration of contaminated droplets' have strong and significant correlation to weather temperature and humidity. Their numerical simulations of droplet spreading through coughing and sneezing has shown that at low temperatures $\left(0^{\circ} \mathrm{C}\right)$ the spread of contaminated respiratory droplets would be quite wider and larger in spatial sense, compared to the spread of droplets at 20C to 40C. Similarly, at high $\mathrm{RH}(50 \% \sim 90 \%)$, the contaminated droplets would thin out less compared to the spread at low RH $(10 \% \sim 30 \%)$. Therefore, in terms of temperature and relative humidity there is a strong correlation between high relative humidity at low temperature and the increased spread of 
medRxiv preprint doi: https://doi.org/10.1101/2021.12.28.21268496; this version posted December 31, 2021. The copyright holder for this preprint (which was not certified by peer review) is the author/funder, who has granted medRxiv a license to display the preprint in perpetuity.

It is made available under a CC-BY-NC-ND 4.0 International license .

47 concentrated and contaminated virus borne droplets. Another study [6] on the evaporation

48 modelling of coughing droplets in high humid areas, where it was found that dry conditions

49 enhance droplet travelling more efficiently than in wet conditions. The evaporation model study

50 arrived in another major conclusion that smaller droplets are not affected by higher relative

51 humidity (60\% to $90 \%)$ compared to bigger droplets. Their final impression is that even though

52 the evaporation model shows significant increase in evaporation rate with bigger droplets, the

53 scarcity of study on the dilution and inactivation of small droplets in low humidity condition makes

54 it difficult to assess the certainty of spreading and suspension of virus borne coughs and sneezes

55 in different regions of the world. Iqbal et al. [7] and Bukhari et al. [8] concluded that coronavirus

56 spread was faster in colder regions compared to warmer region and that there is close relationship

57 between daylight hours, average temperature and risk of COVID infection rate. In different parts

58 of the world, researchers found that there indeed positive correlation between COVID infection

59 rate and humid climate. For instance, Pani et al. [9] found that along with temperature and weaker

60 correlation with relative humidity, dew point and water vapor has positive correlation with

61 COVID-19 in Singapore, a predominantly "hot and humid climate with abundant rainfall". On the

62 other hand, Takagi et al.[10] found negative association of temperature, pressure and UV with

63 COVID-19 prevalence in Japan and exclaimed that the finding of no association of Covid-19 with

64 climatic conditions in China [11] can be possibly argued. Both research papers were published

65 based on the studies done in early period of COVID pandemic in specific geo locations (Chinese

66 cities: Yao et al. [11], published in April 2020 and Japanese cities: Takagi et al. [10] published in

67 August 2020). Similarly, a supportive study results from Japan showed that the epidemic growth

68 has strong correlation to increase in daily temperature[12]. A very recent study done by Zhu et al.

69 [13] looked across various regions in South America but concluded that among other factors, 
medRxiv preprint doi: https://doi.org/10.1101/2021.12.28.21268496; this version posted December 31, 2021. The copyright holder for this preprint (which was not certified by peer review) is the author/funder, who has granted medRxiv a license to display the preprint in perpetuity.

It is made available under a CC-BY-NC-ND 4.0 International license .

absolute humidity was highly negatively correlated to the COVID-19 spread. Across the 122 cities in China, Xie et al. [14] found that at certain threshold temperature of $3 \mathrm{C}$, the mean temperature has positive linear relationship with infection cases and in Iran, humid provinces has higher rate of increase in infection rate and extreme dry regions have proved a reverse relationship[15]. Both in Brazil and Indonesia, Auler et al. [16] and Tosepu et al. [17] found that higher mean temperature and humidity has positive correlation in infection spreading which is in contrast to many other studies done in colder European and US regions[18]. Auler et al. [16] also reported that among the five Brazilian cities, Sao Paulo was the city with highest confirmed cases but with the lowest mean temperature and highest relative humidity. But with further statistical analysis they arrived at the conclusion that the disease transmission rate was favored by high temperature and relatively high humidity. Therefore, it can be assumed from their study that there is no strong correlation but rather several anomalies within a given region, and therefore a sole factor cannot be singled out to have strong impact on the increasing infection rate. In Victoria, Mexico [19] temperature was found to be negatively correlated to the spread of the infection and their study spanned from March 2020 till June 2020 but consequently did not include the sharp rise in infection rate of the second wave in other Mexican cities. Another study on tempered climate stated that tropical climate slows spreading of COVID-19 local transmission, and also reported to have negative association between temperature and local positive cases[20]. A case study based on New Jersey by Doğan et al. [21] produced results indicating that humidity has positive relationship and temperature has negative relationship to COVID-19 based on data collected and analyzed from late February to late July of 2020. They also pointed out that their study outcome is in contradiction to the study by Ahmadi et al. [15] in Iran, which stated that there exist strong correlation between COVID infection and humidity, temperature and wind. An associative study has explored the pathway of COVID-19 
medRxiv preprint doi: https://doi.org/10.1101/2021.12.28.21268496; this version posted December 31, 2021. The copyright holder for this preprint (which was not certified by peer review) is the author/funder, who has granted medRxiv a license to display the preprint in perpetuity.

It is made available under a CC-BY-NC-ND 4.0 International license .

93 spread in Oslo Norway a little differently, where Menebo et al. [22] implied that sunny weather

94 makes people come out of home and rainy weather makes people stay indoors, and hence warm

95 climate triggers an increase in infection and spreading events. Many studies found strong

96 temperature association based on low COVID cases in different countries, as pointed out by [23]

97 and there remains the question as to what happened afterwards with regards to exponential global

98 growth in infection and death inherently affecting different individual regions. Bashir et al. [24]

99 indicated that scientific evidence does not support that warm weather would bring down the

100 epidemic spread contrary to popular misbelief pointed out by many researchers [25] when

101

compared to different influenza and COVID variants [26], [27]. In Spain[28], Iran[29] and in 50

102

US cities[25], studies conducted between February and March showed that there exists no

103

correlation between weather variables and COVID-19, which contradicts to the other studies that

104

found some correlation as discussed before. Even recent observations by Pan et al. [30] implicated

that meteorological factors, including temperature, did not exhibit significant association and

would not help in reducing COVID-19 transmission. Several other studies that studied the mixed

combination of different climatological factors have either found unconvincing or very weak

108

correlation to COVID transmission [31]-[33].

It is also relevant to mention that several studies have [11], [34]-[38]. On the other hand, many

studies have confuted weather factors that were deemed strongly correlated to the rate of spread

112 out that the factors like population density, emergency care and medical treatment, socio-economic

113 conditions of different locations could be coupled with climatic factors and thus disassociating or

114 considering outside temperature or humidity to be a single controlling factor would give false

115 perception, conception and pretense on how SARS-CoV-2 spreads[23], [40]. 
medRxiv preprint doi: https://doi.org/10.1101/2021.12.28.21268496; this version posted December 31, 2021. The copyright holder for this preprint (which was not certified by peer review) is the author/funder, who has granted medRxiv a license to display the preprint in perpetuity.

It is made available under a CC-BY-NC-ND 4.0 International license .

116

117

118

119

120

121

122

123

124

125

126

127

128

129

130

131

132

133

134

135

136

137

138

In this study, our approach to understand and elaborate the difference in correlation between climatic conditions and the coronavirus transmission is based on a total of four countries, two countries that have relatively dry colder climates and two that have tropical humid climates during the period of October to December of 2020. In the later part of the paper, we would demonstrate, as many other research studies already pointed out, that a single climatic factor is not solely responsible for the spread of the coronavirus infection among different types of climate regions.

Part of the problem with statistical correlation is always related to the degree of uncertainty and the risk of over-confidence in statistical representation of the results. While many of the statistical studies are done with relatively low spread of infection (compare to the spread and infection rate of COVID during the summer in US) researchers publishing data based on the late winter (February to April) and Summer is not totally indicative of the link between climate and COVID infection. This became more apparent in our study where we found that the weather model and the rise in infection in cold climatic regions (for instance in Italy, France) is totally opposite to tropical regions (like Brazil and Colombia) during the months of November and December. We acknowledge that climatic factors like outside temperature and humidity alone cannot predict viral transmissibility and the spread of the SARS-CoV-2 infection, rather physiological factors through means of aerosol and infected droplets causing membranous fusion and are found to be dependent on wet-bulb temperature which in turn is a function of indoor/outdoor room temperature, absolute and relative humidity, as investigated by JD Runkle et al. [41] and Dougherty [42], are the active route of transmission for the virus. What is more important to understand is, measure of social distance, mask mandates and part of governing policy regulation including lockdowns are key factors that dictate the rate of infections, not the weather as believed by many including policy makers. 


\section{Methods}

\subsection{Data Collection and Validation}

For this study, weather data is collected from Integrated Surface Database (ISD) from NOAA's National Climatic Data Center (NCDC) [43]. The ISD data from more than 20,000 stations worldwide and consists of different weather identifying subsets including, but not limited to, World Meteorological Organization(WMO), Weather Bureau Army Navy (WBAN), Climate Reference Network (CRN), Federal Aviation Administration (FAA), Automated Surface Observing System (ASOS), and Automated Weather Observing System (AWOS) [44]. With extensive hourly and daily data including air temperature, dew point temperature, maximum and minimum recorded temperatures for the day, and wind speed, this study used the ISD provided data for the entire year of 2020. Several sources are used to collect the daily infection data for each of the four countries: Brazil[45], Italy[46], France[47], and Colombia [48]. Datasets have been crosschecked and validated with John Hopkins Coronavirus Resource Center [49], The New York Times [50], Google [51] and Microsoft Bing[52].

\subsection{Calculation based on Longitude, Latitude and of Relative Humidity (\%RH)}

An extensive algorithm has been developed in MATLAB to study the spreading of COVID infection in two tropical countries Brazil and Colombia, as well as two temperate climate countries, Italy, and France. Regions/cities with highest reported cases in each country were picked and close proximal stations were identified using the longitude and latitude data, while cross checked with the Hourly/Sub-Hourly Observational Data Map [53]. The location and daily COVID cases/hospitalization information were very critical, since some of the hourly data were not available for some of the stations and some of the COVID data had lapses (unreported, erroneous 
medRxiv preprint doi: https://doi.org/10.1101/2021.12.28.21268496; this version posted December 31, 2021. The copyright holder for this preprint (which was not certified by peer review) is the author/funder, who has granted medRxiv a license to display the preprint in perpetuity.

It is made available under a CC-BY-NC-ND 4.0 International license .

161 or skipped reporting). Therefore, careful consideration has been made to locate correct

162 WMO/WBAN stations within the given latitude and longitude combinations for each of the 36

163 regions/states and the weather data were accurately collected and matched with the COVID

164 datasets using the MATLAB algorithm. Using the outside temperature and dewpoint temperature,

165 the Relative Humidity $(\% \mathrm{RH})$ was calculated using the following relationship:

166

$$
R H=100 \times \frac{e^{\left(\frac{17.625 * T_{\text {dewpoint }}}{243.04+T_{\text {dewpoint }}}\right)}}{e^{\left(\frac{17.625 * T_{\text {ambient }}}{243.04+T_{\text {ambient }}}\right)}}
$$

167

\subsection{Analysis}

Weather data and infection rate (in some countries reported as number of cases with Hospitalization) are analyzed from October $1^{\text {st }}$ to December $31^{\text {st }}$. Spearman correlation coefficients with bivariate, two-tailed analysis stating 95\% confidence interval are also reported for each region where the infection and the weather patterns are plotted. (See Supplemental Information for Temperature and Relative Humidity data plotted against highest recorded infection/hospitalization cases for a total of thirty six regions of each of the four countries.)

\section{Results and Discussion}

Since October $1^{\text {st }}$, the outside air temperature started to fall in France and Italy, but a similar pattern was not observed in the two tropical countries considered, namely Brazil and Colombia. Because of the geolocation of Colombia, which is very close to the equator line, the seven-day averaged temperature did not deviate much. For instance, in between October to December, Bogota observed temperature change from $13^{\circ} \mathrm{C}$ to $11.5^{\circ} \mathrm{C}$; Cartagena observed $28^{\circ} \mathrm{C}$ to $27^{\circ} \mathrm{C}$. Except Tolima, all other regions reported very weak to almost no correlation coefficient $\left(\mathrm{r}_{\mathrm{T}}<0.30\right)$ in between air temperature and daily reported cases. Throughout Colombia, the weather classified by 
medRxiv preprint doi: https://doi.org/10.1101/2021.12.28.21268496; this version posted December 31, 2021. The copyright holder for this preprint (which was not certified by peer review) is the author/funder, who has granted medRxiv a license to display the preprint in perpetuity.

It is made available under a CC-BY-NC-ND 4.0 International license .

182 Köppen-Geiger moves from tropical savanna climate (Aw/As) to tropical monsoon (Am) to

183

184

185

186

187

188

189

190

191

192

193

194

195

196

197

198

199

200

201

202

203

204 tropical rainforest climate (Af) the further the reference location moves from the equator line. While Bogotá and Antioquia weathers are classified as oceanic climate $(\mathrm{Cfb})$ and warm tropical (Af) respectively, with outside temperature steadied at $13^{\circ} \mathrm{C}$ and $27^{\circ} \mathrm{C}$ and relative humidity ranging well within $\mathrm{RH} \sim 72 \%$ to $80 \%$, the infection rate kept a steady record regardless of the outside air temperature and relative humidity. Considering only relative humidity $(\mathrm{RH})$, for the highest recording nine departments of Colombia, shows no correlation $\left(\mathrm{r}_{\%} \mathrm{RH}<0.20\right)$, even though the relative humidity for Valle del Cauca, Norte de Santander, Huila, and Tolima were within the range of $\mathrm{RH}<71 \%$ and Cartagena, Santander and Atlantico had steady record of $\mathrm{RH}>80 \%$. Thus, in both cases of air temperature and relative humidity, throughout Colombia there was very little correlation between weather and the spread of the second wave of COVID-19 infection through the months of October till December.

In Brazil, a widely varying climate is observed across all the regions, and in between October $1^{\text {st }}$ and December $31^{\text {st }}$, except for Santa Catarina and Rio Grande do Sul, the temperature varied in between $35^{\circ} \mathrm{C}$ to $25^{\circ} \mathrm{C}$. Outside temperature for Santa Catarina and Rio Grande do Sul distributed between $25^{\circ} \mathrm{C}$ and $15^{\circ} \mathrm{C}$, and the Köppen-Geiger classification for both states is considered as Aw (tropical savanna climate) and Cwa (dry-winter humid subtropical climate). In both states from mid-October to the end of December, the recorded infection/hospitalization rose from average of 2000 to 5000 and the Spearman correlation coefficient indicated a no correlation ( $\mathrm{r}_{\mathrm{T}}$, Santa Catarina $~$ $0.18, p$-value $>0.05$ ) to weak correlation ( $\mathrm{r}_{\mathrm{T}}$, Rio Grande do Sul $\sim 0.41, p$-value $<0.05$ ). Rio de Janeiro, Goias, and Ceara, all within the Aw (tropical savanna climate with dry-winter characteristics) has experienced an average of 3700 daily cases with little deviation from mean. With Ceará having hot-overall weather throughout region, the COVID infection kept spreading when the weather was 
medRxiv preprint doi: https://doi.org/10.1101/2021.12.28.21268496; this version posted December 31, 2021. The copyright holder for this preprint (which was not certified by peer review) is the author/funder, who has granted medRxiv a license to display the preprint in perpetuity.

It is made available under a CC-BY-NC-ND 4.0 International license .

205 within the overall dryer climate. On the other hand, in Goiás, the second wave was within the rainy 206 season (October-April), but the infection rate soared throughout the time. Relative humidity for

207 both Ceará and Goiás fluctuated between $40 \%$ to $60 \%$ while in Rio de Janeiro the average RH

$20880 \%$, but calculated correlation coefficient were still very insignificant ( $\mathrm{r} \%$ RH, Rio de Janeiro, Goiás, Ceará

$209 \sim-0.07,-0.23,-0.03, p$-value $>0.05)$. In Rio de Janeiro, weather moved from spring to hot-humid

210 summer from October to December, but infection record remained within 3700 cases every day.

211 In no correlation ( $\mathrm{r}_{\mathrm{T}}$, Rio de Janeiro, Goiás, Ceará $\sim-0.11,0.21,-0.02, p$-value $>0.05$ ) between the

212 temperatures and the infection cases, thus the spread of COVID infection has very little correlation

213 within this study period for Brazil.

\begin{tabular}{|c|c|c|c|c|c|c|}
\hline Colombia & \multicolumn{2}{|c|}{ Spearman's correlation coefficient } & Population & Population Density $\left(/ \mathrm{km}^{2}\right)$ & Reported Cases & Reported Case / Per Capita \\
\hline Bogotá, Capital District & 0.03 & 0.01 & $7,412,566$ & 17,994 & 471,155 & N/A \\
\hline Antioquia & -0.01 & -0.08 & $6,407,102$ & 100 & 261,592 & N/A \\
\hline Valle del Cauca & -0.1 & 0.19 & $4,475,886$ & 200 & 137,867 & N/A \\
\hline Atlántico & -0.04 & -0.04 & $2,535,517$ & 75 & 93,975 & N/A \\
\hline Santander & 0.01 & 0.12 & $2,184,837$ & 72 & 67,114 & N/A \\
\hline Norte de Santander & -0.16 & 0.17 & $1,491,689$ & 69 & 40347 & N/A \\
\hline Cartagena, Bolivar & 0.01 & -0.03 & 914,552 & 1,600 & 51799 & N/A \\
\hline Tolima & -0.35 & 0.19 & $1,330,187$ & 56 & 44138 & N/A \\
\hline Huila & -0.02 & -0.13 & $1,100,386$ & 55 & 34880 & N/A \\
\hline
\end{tabular}

216 Figure 1: Spearman's Correlation for Temperature and Relative Humidity vs Nine states/regions 217 with highest COVID infection by the end of December $31^{\text {st }}, 2020$ of a) Top: Colombia and b) 
medRxiv preprint doi: https://doi.org/10.1101/2021.12.28.21268496; this version posted December 31, 2021. The copyright holder for this preprint (which was not certified by peer review) is the author/funder, who has granted medRxiv a license to display the preprint in perpetuity.

It is made available under a CC-BY-NC-ND 4.0 International license .
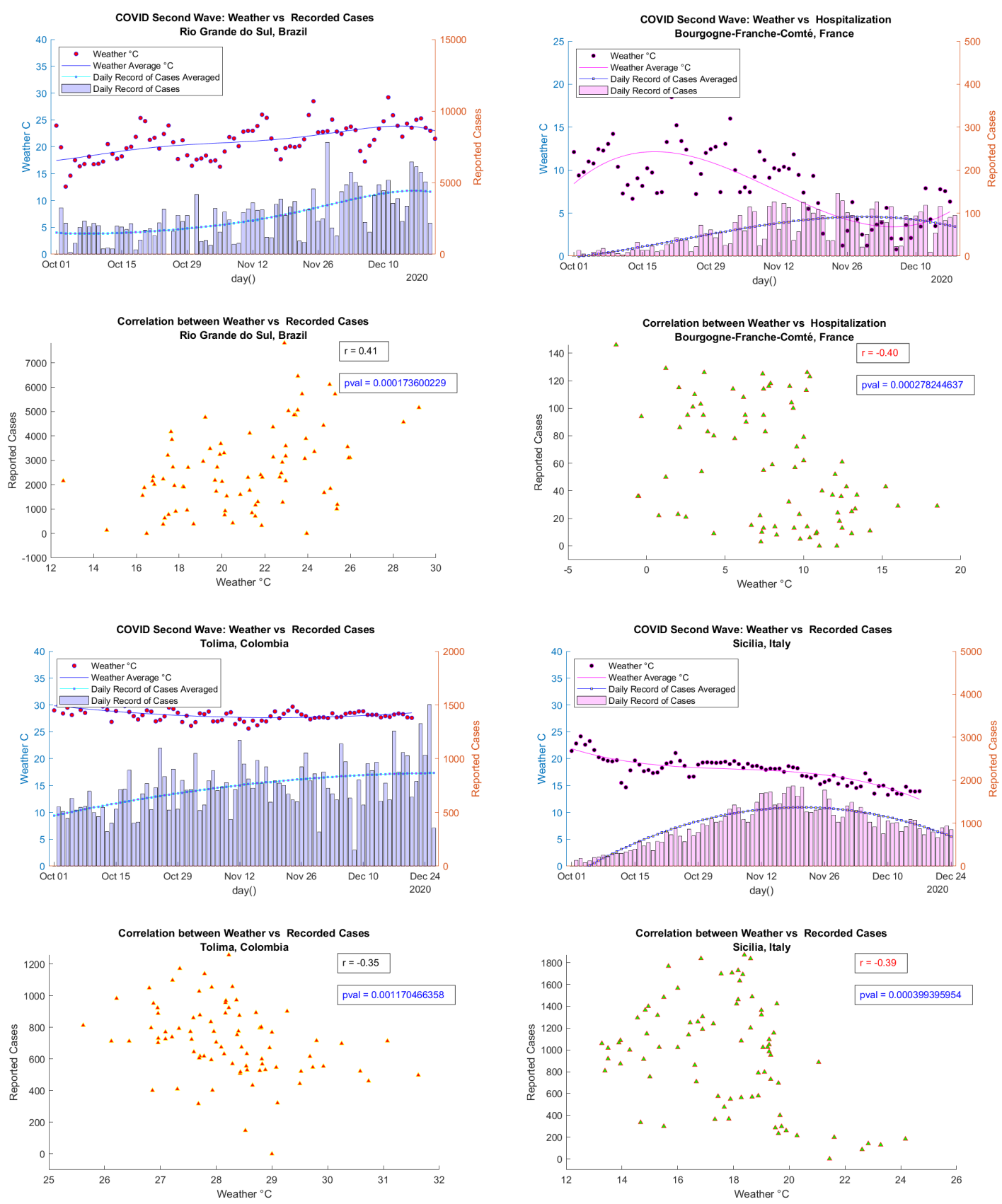

Figure 2: Comparison between recorded outside temperature patterns and the COVID infection of four different regions for two different climate types: 
medRxiv preprint doi: https://doi.org/10.1101/2021.12.28.21268496; this version posted December 31, 2021. The copyright holder for this preprint (which was not certified by peer review) is the author/funder, who has granted medRxiv a license to display the preprint in perpetuity. It is made available under a CC-BY-NC-ND 4.0 International license .


Figure 3: Köppen-Geiger classification of four countries: Top: Brazil (left), Colombia (right) Bottom: France (left), Italy (right) [54]-[58]

For colder climates, by the end of the year 2020, France and Italy recorded a total of 2.64 million (3.94\% of the total population) and 2.14 million cases (3.55\% of the total population), respectively. On the other hand, Colombia had an estimated of 1.67 million cases (3.28\% of the total population) and Brazil had 7.72 million cases of infected people (3.62\% of the total population). All four countries considered in this study have varying climate patterns, as shown in Figure 3, even though

233 the proportions of people infected with the virus by the end of 2020 are approximately very similar.

234 From the very beginning of October till mid-December, nine of the regions with the most recorded COVID cases in France, observed a constant fall in temperature, with an average shift of mean temperature from $13^{\circ} \mathrm{C}$ to $7^{\circ} \mathrm{C}$. This observation is reflected in the correlation coefficient, 
medRxiv preprint doi: https://doi.org/10.1101/2021.12.28.21268496; this version posted December 31, 2021. The copyright holder for this preprint (which was not certified by peer review) is the author/funder, who has granted medRxiv a license to display the preprint in perpetuity.

It is made available under a CC-BY-NC-ND 4.0 International license.

237 especially in Auvergne-Rhone-Alpes (ARA), Grand Est (GE), and Bourgogne-Franche-Comte

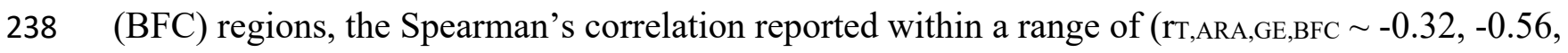

$239-0.40, p$-value $<0.001)$. COVID cases, except in the case of Grand Est, is not significantly

240 correlated to the reported related humidity.

\begin{tabular}{|c|c|c|c|c|c|c|}
\hline France & \multicolumn{2}{|c|}{ Spearman's correlation coefficient } & Population & Population Density $\left(/ \mathrm{km}^{2}\right)$ & Reported Cases & Reported Case / Per Capita \\
\hline Ile-de-France & -0.11 & -0.18 & $12,278,210$ & 52 & 71596 & 583 \\
\hline Auvergne-Rhone-Alpes & -0.32 & -0.06 & $7,948,287$ & 110 & 38,925 & 477 \\
\hline Grand Est & -0.56 & 0.34 & $5,549,586$ & 97 & 30,215 & 538 \\
\hline Provence-Alpes-Cote d'Azur & -0.09 & -0.16 & $5,007,977$ & 160 & 24,807 & 491 \\
\hline Hauts-de-France & -0.21 & 0.06 & $6,009,976$ & 190 & 24,693 & 407 \\
\hline Bourgogne-Franche-Comte & -0.4 & 0.28 & $2,811,423$ & 59 & 14,265 & 499 \\
\hline Occitanie & -0.05 & 0.06 & $5,839,867$ & 80 & 13,582 & 227 \\
\hline Normandie & -0.23 & 0.07 & $3,322,757$ & 110 & 8,460 & 252 \\
\hline Pays de la Loire & -0.27 & 0.11 & $3,553,352$ & 110 & 8,354 & 216 \\
\hline
\end{tabular}

\begin{tabular}{|c|c|c|c|c|c|c|}
\hline \multirow{2}{*}{ Italy } & \multicolumn{2}{|c|}{ Spearman's correlation coefficient } & \multirow{2}{*}{ Population } & \multirow{2}{*}{ Population Density $\left(/ \mathrm{km}^{2}\right)$} & \multirow{2}{*}{ Reported Cases } & \multirow{2}{*}{ Reported Case / Per Capita } \\
\hline & $r_{T^{\circ}}$ & $r_{\% R H}$ & & & & \\
\hline Lombardia & -0.06 & 0.31 & $1010,103,969$ & 420 & 478,903 & 4,760 \\
\hline Veneto & -0.68 & 0.10 & $4,865,380$ & 260 & 253,875 & 5,175 \\
\hline Piedmonte & -0.08 & 0.07 & $4,322,805$ & 170 & 197,828 & 4,541 \\
\hline Campania & -0.04 & 0.25 & $5,869,029$ & 430 & 189,673 & 3,269 \\
\hline Emilia-Romagna & -0.55 & 0.35 & $4,446,220$ & 200 & 171,512 & 3,846 \\
\hline Lazio & -0.13 & 0.13 & $5,864,321$ & 340 & 163,051 & 2,773 \\
\hline Toscana & 0.13 & -0.04 & $3,722,729$ & 160 & 120,328 & 3,226 \\
\hline Sicilia & -0.39 & 0.32 & $4,969,147$ & 190 & 93,644 & 1,873 \\
\hline Puglia & -0.71 & 0.65 & $4,063,888$ & 210 & 90,964 & 2,258 \\
\hline
\end{tabular}

243 Figure 4: Spearman's Correlation for Temperature and Relative Humidity vs Nine states/regions with highest COVID infection by the end of December $31^{\text {st }}, 2020$ of a) Top: France and b)

246 The COVID second wave in Italy has indicated an overall strong to moderate correlation in regions

247 like Veneto ( $\mathrm{r}_{\mathrm{T}}$, Veneto $\sim-0.68, p$-value $\left.>0.05\right)$, Emilia-Romagna ( $\mathrm{r}_{\mathrm{T}}$, Emilia-Romagna $\sim-0.55, p$ -

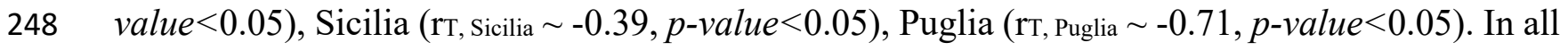

249 Veneto and Emilia-Romagna, the outside weather dropped from 16C to 6C, whereas in Sicilia the

250 temperature dropped from $21 \mathrm{C}$ to $13 \mathrm{C}$ and in Puglia 20C to $7 \mathrm{C}$. In Veneto and Emilia-Romagna,

251 the cases rose from 1000/cases per day to 2000/cases per day, and in Sicilia and Puglia, the cases

252 rose from 250/cases per day to 1000/cases per day. Both in France and Italy, regions like Grand

253 Est (Fr), Bourgogne-Franche-Comte (Fr), Lombardia (Italy) and Emili-Romagna (Italy), infection

254 rate has weak correlation to relative humidity $\left(\mathrm{r}_{\mathrm{R}} \mathrm{RH}<0.35\right.$, $p$-value $\left.<0.05\right)$. 
medRxiv preprint doi: https://doi.org/10.1101/2021.12.28.21268496; this version posted December 31, 2021. The copyright holder for this preprint (which was not certified by peer review) is the author/funder, who has granted medRxiv a license to display the preprint in perpetuity.

It is made available under a CC-BY-NC-ND 4.0 International license .
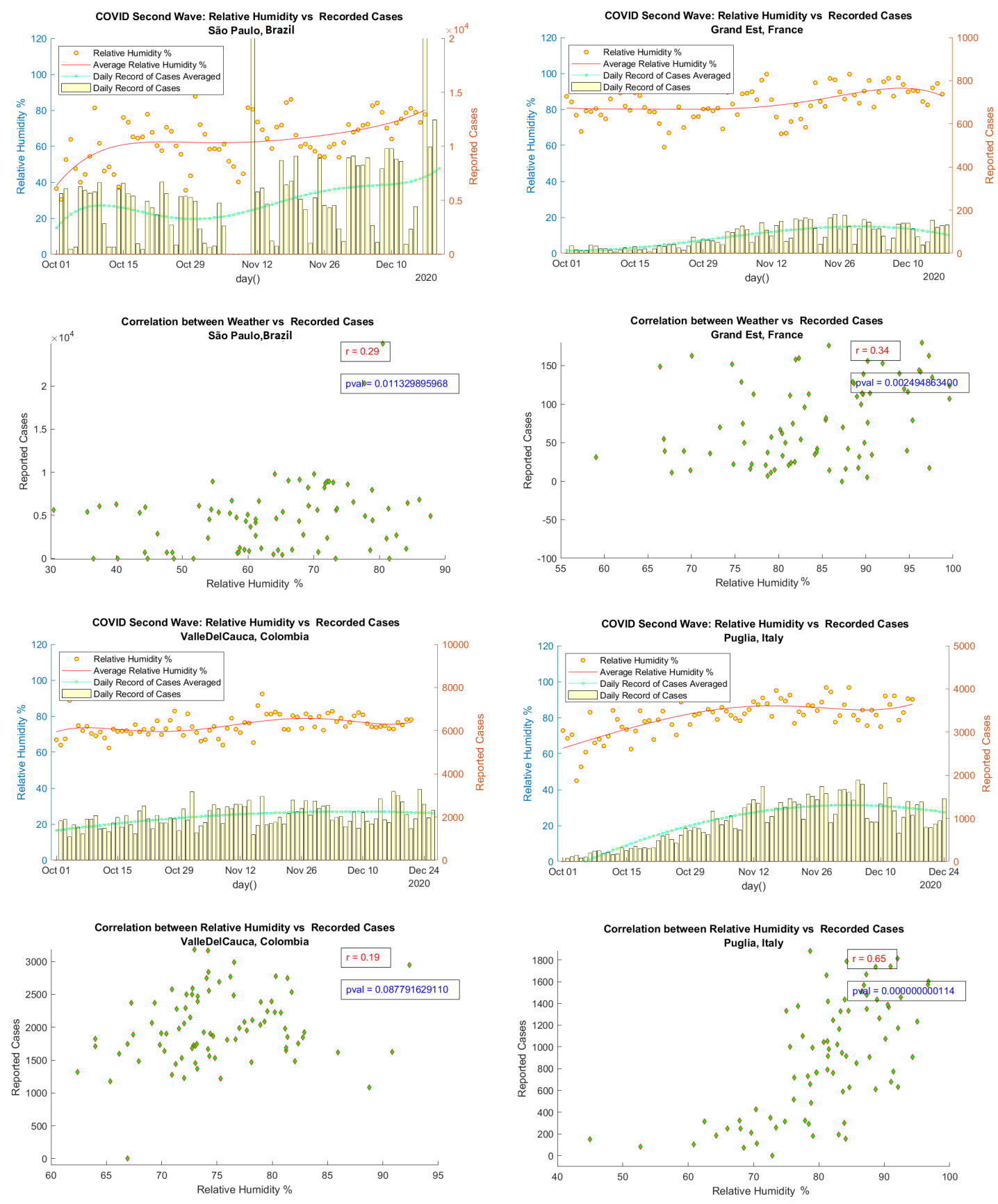

256

257

258

259

Figure 5: Comparison between relative humidity $(\% \mathrm{RH})$ and the COVID infection of four different regions for two different climate types:

São Paulo, Brazil (r=0.29); Grand Est, France (r=0.34);

Valle del Cauca, Colombia $(\mathrm{r}=0.19)$; Puglia, Italy $(\mathrm{r}=0.65)$ 
medRxiv preprint doi: https://doi.org/10.1101/2021.12.28.21268496; this version posted December 31, 2021. The copyright holder for this preprint (which was not certified by peer review) is the author/funder, who has granted medRxiv a license to display the preprint in perpetuity.

It is made available under a CC-BY-NC-ND 4.0 International license .

261 Even though a thorough study has been made available through this study, a wider look into the

262 dryer climates in middle east, or a varying climatic zone of Australia and colder climates in Canada

263 and Russia could have strengthen the findings and help build a more extensive study on the effect

264 of weather patterns and the spread of COVID infection. A further look into a combination of

265 weather and relative humidity, such like wet-bulb temperature, or other factors like absolute

266 humidity, heat index in dry climate areas should be further explored.

\section{Conclusion}

268 This study sheds light into the detail of more than 36 regions with widely varying weather patterns.

269 While outside temperature may seem to hold good correlation and might support the hypothesis

270 that outside temperature effects the rate of spread of COVID infection in cold climates such like

271 Italy and France, this hypothesis across warmer humid tropical climates does not hold to be true.

272 With a falling seven-day average outside temperature seemingly causes a rise in infection rate in

273 Italy and France, a very little fluctuation in temperature could not stop the spread of COVID-19 in

274 Colombia. While many of the recent scientific research exploring the strength of correlation

275 between weather and the spread of SARS-CoV-2 may seem to be producing conjectures that are

276 quite convincing, based on this literature findings the notion that COVID-19 is heavily dependable

277 on climate pattern is not convincible and therefore remains quite debatable. 
medRxiv preprint doi: https://doi.org/10.1101/2021.12.28.21268496; this version posted December 31, 2021. The copyright holder for this preprint (which was not certified by peer review) is the author/funder, who has granted medRxiv a license to display the preprint in perpetuity. It is made available under a CC-BY-NC-ND 4.0 International license .

\section{Credit authorship contribution statement}

283 Ahmed Islam: Algorithm Development, Resources and Data collection and analysis, Writing -

284 original draft.

285 Declaration of competing interest

286

The authors declare that they have no known competing financial interests or personal

287 relationships that could have appeared to influence the work reported in this paper.

288

289

290

291

292

293

294

295

296

297

298

299

300

References 
medRxiv preprint doi: https://doi.org/10.1101/2021.12.28.21268496; this version posted December 31, 2021. The copyright holder for this preprint (which was not certified by peer review) is the author/funder, who has granted medRxiv a license to display the preprint in perpetuity.

It is made available under a CC-BY-NC-ND 4.0 International license .

301 [1] M. Cevik, C. G. G. Bamford, and A. Ho, "COVID-19 pandemic-a focused review for clinicians," Clin. Microbiol. Infect., vol. 26, no. 7, pp. 842-847, Jul. 2020, doi: 10.1016/j.cmi.2020.04.023.

[2] D. Fisman, "Seasonality of viral infections: Mechanisms and unknowns," Clinical Microbiology and Infection. 2012, doi: 10.1111/j.1469-0691.2012.03968.x.

[3] M. Moriyama, W. J. Hugentobler, and A. Iwasaki, "Seasonality of Respiratory Viral Infections," Annu. Rev. Virol., 2020, doi: 10.1146/annurev-virology-012420-022445.

[4] A. C. Lowen, S. Mubareka, J. Steel, and P. Palese, "Influenza virus transmission is dependent on relative humidity and temperature," PLoS Pathog., 2007, doi: 10.1371/journal.ppat.0030151.

[5] T. Dbouk and D. Drikakis, "Weather impact on airborne coronavirus survival," Phys. Fluids, 2020, doi: 10.1063/5.0024272. cough droplets in tropical outdoor environment," Phys. Fluids, 2020, doi: $10.1063 / 5.0026360$.

[7] M. M. Iqbal, I. Abid, S. Hussain, N. Shahzad, M. S. Waqas, and M. J. Iqbal, “The effects of regional climatic condition on the spread of COVID-19 at global scale," Sci. Total Environ., 2020, doi: 10.1016/j.scitotenv.2020.140101. coronavirus pandemic," Int. J. Environ. Res. Public Health, 2020, doi: 10.3390/ijerph17155399. 
medRxiv preprint doi: https://doi.org/10.1101/2021.12.28.21268496; this version posted December 31, 2021. The copyright holder for this preprint (which was not certified by peer review) is the author/funder, who has granted medRxiv a license to display the preprint in perpetuity.

It is made available under a CC-BY-NC-ND 4.0 International license .

322 [9] S. K. Pani, N. H. Lin, and S. RavindraBabu, "Association of COVID-19 pandemic with

323

324

325

326

327

328

329

330

331

332

333

334

335

336

337

338

339

340

341

342

meteorological parameters over Singapore,"Sci. Total Environ., 2020, doi:

10.1016/j.scitotenv.2020.140112.

[10] H. Takagi et al., "Higher Temperature, Pressure, and Ultraviolet Are Associated With Less COVID-19 Prevalence: Meta-Regression of Japanese Prefectural Data," Asia-Pacific Journal of Public Health. 2020, doi: 10.1177/1010539520947875.

[11] Y. Yao et al., "No association of COVID-19 transmission with temperature or UV radiation in Chinese cities," European Respiratory Journal. 2020, doi:

10.1183/13993003.00517-2020.

[12] K. Azuma, N. Kagi, H. Kim, and M. Hayashi, "Impact of climate and ambient air pollution on the epidemic growth during COVID-19 outbreak in Japan," Environ. Res., 2020, doi: 10.1016/j.envres.2020.110042.

[13] L. Zhu et al., "Meteorological impact on the COVID-19 pandemic: A study across eight severely affected regions in South America," Sci. Total Environ., 2020, doi:

10.1016/j.scitotenv.2020.140881.

[14] J. Xie and Y. Zhu, "Association between ambient temperature and COVID-19 infection in 122 cities from China," Sci. Total Environ., 2020, doi: 10.1016/j.scitotenv.2020.138201.

[15] M. Ahmadi, A. Sharifi, S. Dorosti, S. Jafarzadeh Ghoushchi, and N. Ghanbari, "Investigation of effective climatology parameters on COVID-19 outbreak in Iran," Sci. Total Environ., 2020, doi: 10.1016/j.scitotenv.2020.138705.

[16] A. C. Auler, F. A. M. Cássaro, V. O. da Silva, and L. F. Pires, "Evidence that high 
medRxiv preprint doi: https://doi.org/10.1101/2021.12.28.21268496; this version posted December 31, 2021. The copyright holder for this preprint (which was not certified by peer review) is the author/funder, who has granted medRxiv a license to display the preprint in perpetuity.

It is made available under a CC-BY-NC-ND 4.0 International license .

temperatures and intermediate relative humidity might favor the spread of COVID-19 in tropical climate: A case study for the most affected Brazilian cities," Sci. Total Environ., 2020, doi: 10.1016/j.scitotenv.2020.139090.

[17] R. Tosepu et al., "Correlation between weather and Covid-19 pandemic in Jakarta, Indonesia," Sci. Total Environ., 2020, doi: 10.1016/j.scitotenv.2020.138436.

[18] H. Li, X. L. Xu, D. W. Dai, Z. Y. Huang, Z. Ma, and Y. J. Guan, “Air pollution and temperature are associated with increased COVID-19 incidence: A time series study," Int. J. Infect. Dis., 2020, doi: 10.1016/j.ijid.2020.05.076.

[19] E. Tello-Leal and B. A. Macías-Hernández, “Association of environmental and meteorological factors on the spread of COVID-19 in Victoria, Mexico, and air quality during the lockdown," Environ. Res., 2020, doi: 10.1016/j.envres.2020.110442.

[20] F. Méndez-Arriaga, "The temperature and regional climate effects on communitarian COVID-19 contagion in Mexico throughout phase 1," Sci. Total Environ., 2020, doi: 10.1016/j.scitotenv.2020.139560.

[21] B. Doğan, M. Ben Jebli, K. Shahzad, T. H. Farooq, and U. Shahzad, "Investigating the Effects of Meteorological Parameters on COVID-19: Case Study of New Jersey, United States,” Environ. Res., 2020, doi: 10.1016/j.envres.2020.110148.

[22] M. M. Menebo, “Temperature and precipitation associate with Covid-19 new daily cases: A correlation study between weather and Covid-19 pandemic in Oslo, Norway," Sci. Total Environ., 2020, doi: 10.1016/j.scitotenv.2020.139659.

[23] D. Paraskevis et al., "A review of the impact of weather and climate variables to COVID- 
medRxiv preprint doi: https://doi.org/10.1101/2021.12.28.21268496; this version posted December 31, 2021. The copyright holder for this preprint (which was not certified by peer review) is the author/funder, who has granted medRxiv a license to display the preprint in perpetuity.

It is made available under a CC-BY-NC-ND 4.0 International license .

19: In the absence of public health measures high temperatures cannot probably mitigate outbreaks," Sci. Total Environ., 2021, doi: 10.1016/j.scitotenv.2020.144578.

[24] M. F. Bashir et al., "Correlation between climate indicators and COVID-19 pandemic in New York, USA,”Sci. Total Environ., 2020, doi: 10.1016/j.scitotenv.2020.138835.

[25] S. Gupta, G. S. Raghuwanshi, and A. Chanda, "Effect of weather on COVID-19 spread in the US: A prediction model for India in 2020," Sci. Total Environ., 2020, doi: 10.1016/j.scitotenv.2020.138860.

[26] L. M. Casanova, S. Jeon, W. A. Rutala, D. J. Weber, and M. D. Sobsey, "Effects of air temperature and relative humidity on coronavirus survival on surfaces," Appl. Environ. Microbiol., 2010, doi: 10.1128/AEM.02291-09.

[27] K. Bloom-Feshbach et al., "Latitudinal Variations in Seasonal Activity of Influenza and Respiratory Syncytial Virus (RSV): A Global Comparative Review,” PLoS ONE. 2013, doi: 10.1371/journal.pone.0054445.

[28] Á. Briz-Redón and Á. Serrano-Aroca, "A spatio-temporal analysis for exploring the effect of temperature on COVID-19 early evolution in Spain," Sci. Total Environ., 2020, doi: 10.1016/j.scitotenv.2020.138811.

[29] M. Jahangiri, M. Jahangiri, and M. Najafgholipour, "The sensitivity and specificity analyses of ambient temperature and population size on the transmission rate of the novel coronavirus (COVID-19) in different provinces of Iran," Sci. Total Environ., 2020, doi: 10.1016/j.scitotenv.2020.138872.

[30] J. Pan et al., "Warmer weather unlikely to reduce the COVID-19 transmission: An 
medRxiv preprint doi: https://doi.org/10.1101/2021.12.28.21268496; this version posted December 31, 2021. The copyright holder for this preprint (which was not certified by peer review) is the author/funder, who has granted medRxiv a license to display the preprint in perpetuity.

It is made available under a CC-BY-NC-ND 4.0 International license .

ecological study in 202 locations in 8 countries," Sci. Total Environ., 2021, doi: 10.1016/j.scitotenv.2020.142272.

[31] P. Jüni et al., "Impact of climate and public health interventions on the COVID-19 pandemic: A prospective cohort study," CMAJ, 2020, doi: 10.1503/cmaj.200920.

[32] M. A. Zoran, R. S. Savastru, D. M. Savastru, and M. N. Tautan, “Assessing the relationship between surface levels of PM2.5 and PM10 particulate matter impact on COVID-19 in Milan, Italy," Sci. Total Environ., 2020, doi:

10.1016/j.scitotenv.2020.139825.

[33] M. F. F. Sobral, G. B. Duarte, A. I. G. da Penha Sobral, M. L. M. Marinho, and A. de Souza Melo, “Association between climate variables and global transmission oF SARSCoV-2,”Sci. Total Environ., 2020, doi: 10.1016/j.scitotenv.2020.138997.

[34] S. Kodera, E. A. Rashed, and A. Hirata, "Correlation between COVID-19 morbidity and mortality rates in Japan and local population density, temperature, and absolute humidity," Int. J. Environ. Res. Public Health, 2020, doi: 10.3390/ijerph17155477.

[35] Y. Zhu and J. Xie, "Association between ambient temperature and COVID-19 infection in 122 cities from China," Sci. Total Environ., 2020.

[36] B. F. Zaitchik et al., "A framework for research linking weather, climate and COVID-19," Nature Communications. 2020, doi: 10.1038/s41467-020-19546-7.

[37] Á. Briz-Redón and Á. Serrano-Aroca, "The effect of climate on the spread of the COVID19 pandemic: A review of findings, and statistical and modelling techniques," Prog. Phys. Geogr., 2020, doi: 10.1177/0309133320946302. 
medRxiv preprint doi: https://doi.org/10.1101/2021.12.28.21268496; this version posted December 31, 2021. The copyright holder for this preprint (which was not certified by peer review) is the author/funder, who has granted medRxiv a license to display the preprint in perpetuity.

It is made available under a CC-BY-NC-ND 4.0 International license .

406

407

408

409

410

411

412

413

414

415

416

417

418

419

420

421

422

423

424

425

426

[38] C. J. Carlson, A. C. R. Gomez, S. Bansal, and S. J. Ryan, "Misconceptions about weather and seasonality must not misguide COVID-19 response," Nature Communications. 2020, doi: 10.1038/s41467-020-18150-z.

[39] E. A. Rashed, S. Kodera, J. Gomez-Tames, and A. Hirata, "Influence of absolute humidity, temperature and population density on COVID-19 spread and decay durations: Multi-prefecture study in Japan," Int. J. Environ. Res. Public Health, 2020, doi: 10.3390/ijerph17155354.

[40] M. T. P. Coelho et al., "Exponential phase of covid19 expansion is driven by airport connections," medRxiv. 2020, doi: 10.1101/2020.04.02.20050773.

[41] Runkle, Jennifer D., et al. "Short-term effects of specific humidity and temperature on COVID-19 morbidity in select US cities." Science of the Total Environment 740 (2020): 140093.

[42] R. Dougherty, Wet-Bulb Temperature Modulates SARS-CoV-2 Superspreading Events. 2020.

[43] NOAA, "Global Summary of the Day," Index of /pub/data/gsod/2020/. ftp://ftp.ncdc.noaa.gov/pub/data/gsod/2020/.

[44] A. Smith, N. Lott, and R. Vose, "The integrated surface database: Recent developments and partnerships,” Bull. Am. Meteorol. Soc., 2011, doi: 10.1175/2011BAMS3015.1.

[45] H. Moraes, "https://github.com/elhenrico/covid19-Brazil-timeseries." https://github.com/elhenrico/covid19-Brazil-timeseries.

[46] P. del C. dei M.-D. della P. Civile, "Dati COVID-19 Italia.” https://github.com/pcm- 
medRxiv preprint doi: https://doi.org/10.1101/2021.12.28.21268496; this version posted December 31, 2021. The copyright holder for this preprint (which was not certified by peer review) is the author/funder, who has granted medRxiv a license to display the preprint in perpetuity.

It is made available under a CC-BY-NC-ND 4.0 International license .

427

428

429

430

431

432

433

434

435

436

437

438

439

440

441

442

443

444

445

446

447
dpc/COVID-19.

[47] Institut National des Statistiques et des Études Économiques, “Institut National des Statistiques et des Études Économiques.” https://github.com/rozierguillaume/covid-19.

[48] I. N. de Salud and M. de T. de la I. y las Comunicaciones, "Instituto Nacional de Salud;" https://www.gov.co/home/.

[49] Johns Hopkins University \& Medicine, "Coronavirus Resource Center Johns Hopkins University \& Medicine." https://coronavirus.jhu.edu/.

[50] The New York Times, "NYTIMES: Coronavirus (Covid-19) Data in the United States." https://github.com/nytimes/covid-19-data.

[51] Google Cloud Platform, "COVID-19 Open-Data."

https:/github.com/GoogleCloudPlatform/covid-19-open-data.

[52] Microsoft; Bing, "Microsoft Bing COVID-19 Data." https://github.com/microsoft/BingCOVID-19-Data/blob/master/data/Bing-COVID19-Data.csv.

[53] NOAA, "Hourly/Sub-Hourly Observational Data Map." https://gis.ncdc.noaa.gov/maps/ncei/cdo/hourly.

[54] M. Kottek, J. Grieser, C. Beck, B. Rudolf, and F. Rubel, "World map of the KöppenGeiger climate classification updated," Meteorol. Zeitschrift, 2006, doi: 10.1127/09412948/2006/0130.

[55] M. C. Peel, B. L. Finlayson, and T. A. McMahon, "Updated world map of the KöppenGeiger climate classification," Hydrol. Earth Syst. Sci., 2007, doi: 10.5194/hess-11-16332007. 
medRxiv preprint doi: https://doi.org/10.1101/2021.12.28.21268496; this version posted December 31, 2021. The copyright holder for this preprint (which was not certified by peer review) is the author/funder, who has granted medRxiv a license to display the preprint in perpetuity. It is made available under a CC-BY-NC-ND 4.0 International license .

448 [56] R. Geiger, "Classificação climática de Köppen- Geiger," Creat. Commons Attrib. Alike $449 \quad 3.0$ Unported, 1936.

450 [57] F. Rubel and M. Kottek, "Observed and projected climate shifts 1901-2100 depicted by world maps of the Köppen-Geiger climate classification,” Meteorol. Zeitschrift, 2010, doi:

452 10.1127/0941-2948/2010/0430.

453 [58] B. Warf, "Köppen-Geiger Climate Classification," in Encyclopedia of Geography, 2014. 